\title{
PRIORITIZING THE BANKING SERVICE QUALITY OF DIFFERENT BRANCHES USING FACTOR ANALYSIS, AHP AND TOPSIS METHODOLOGY-A CASE STUDY
}

\author{
G.V.S.K.Gautham ${ }^{1}$, Dr.G.Ram Babu ${ }^{2}$, D.Balaji Naik ${ }^{3}$, G.Gandhi Krishna ${ }^{4}$ \\ ${ }^{1}$ Department of Mechanical Engg, Andhra University, Visakhapatnam-530 007 \\ ${ }^{2}$ Department of Mechanical Engg, Andhra University, Visakhapatnam-530 007 \\ ${ }^{3}$ Department of Mechanical Engg, Andhra University, Visakhapatnam-530 007 \\ ${ }^{4}$ Manager,MMGS-III,State Bank of India
}

\begin{abstract}
In recent years, India's service industry is developing rapidly. The objective of the study is to explore the dimensions of customer perceived service quality in the context of the Indian banking industry. In order to categorize the customer needs into quality dimensions, Factor analysis (FA) has been carried out on customer responses obtained through questionnaire survey. Analytic Hierarchy Process (AHP) is employed to determine the weights of the banking service quality dimensions. The priority structure of the quality dimensions provides an idea for the Banking management to allocate the resources in an effective manner to achieve more customer satisfaction. Technique for Order Preference Similarity to Ideal Solution (TOPSIS) is used to obtain final ranking of different branches.
\end{abstract}

\section{KEYWORDS}

Service Quality, Factor analysis, Analytic Hierarchy Process, Technique for Order Preference Similarity to Ideal Solution.

\section{INTRODUCTION}

Banking sector in India is sound, adequately capitalized and well-regulated. It has always been one of the most preferred destinations for employment. In this decade, this sector has emerged as a sunrise sector in Indian economy. A large number of people are engaged with this sector from staff to executive level to operate the whole system.The major challenge to this sector at present is to ensure expected quality of service that the customer wishes.

Factor analysis is one of the very useful techniques to summarize a large amount of data in a manageable way. Factor analysis attempts to identify underlying variables, or factors, that explain the pattern of correlations within a set of observed variables. Factor analysis is often used in data reduction to identify a small number of factors that explain most of the variance observed in a much larger number of manifest variables. It may used to define a relationship among sets of 
many interrelated variables to be examined and represented in terms of a few underlying factors. This technique is applicable to identify the underlying dimensions or factors that explain the correlations among a set of variables. Factor analysis can be employed to determine the brand attributes that influence customer choice. In the current study this technique is used to determine the factors that influence the quality of banking service. The overall banking service is interdependent on the service attributes. The quality of those service attributes dominates the satisfaction of overall service of customer and this relationship can be depicted through a linear model stating overall satisfaction as dependent and others service attributes as independent variable.

Analytic hierarchy process (AHP) is a structured technique for organizing and analyzing complex decisions .It is a multi-criteria decision making (MCDM) technique proposed by Saaty. It is a theory of measurement through pair wise comparisons and relies on the judgments of experts to derive priority scales. It is the scale that measure intangibles in relative terms. The comparisons are made using a scale of absolute judgments that represents, how much more one element dominates another with respect to a given attribute. The judgments may be inconsistent, how to measure inconsistency and improve the judgments, when possible to obtain better consistency is a concern of the AHP. The derived priority scales are synthesized by multiplying them by the priority of their parent nodes and adding for all such nodes.

Technique for Order Preference by Similarity to Ideal Solution (TOPSIS) was set forth by Hwang and Lin (1987). In this technique, " $n$ " different alternatives are evaluated by " $m$ " different attributes, the attributes being common to all the alternatives. The method belongs to MCDM (Multiple Criteria Decision Making) group of methods and identifies solutions from a finite set of alternatives based upon simultaneous minimization of distance from an ideal point and maximization of distance from a negative ideal point. Hence ranking of different alternatives can be done with the help of TOPSIS methodology.

\section{METHODOLOGY}

\subsection{Factor analysis}

Factor analysis is carried out with a view to reduce the list of customer attributes. The data received from the questionnaire survey was carried out using statistical package for social sciences (SPSS) version 16.0. The factor analysis begins with the correlation matrix, in which the inter-correlations between the studied variables (customer attributes) are presented. The sample adequacy for the response data is examined through KMO and Bartlett's tests. Communalities are determined and rotated component matrix is prepared. Scree plot is obtained for the data to identify the appropriate factors. Factors obtained through factor analysis are grouped and AHP methodology is employed to find out the weights.

\subsection{Analytical hierarchy process}

Step 1: Establishment of pair-wise comparison matrix

Setup the pair-wise comparison matrix of order $n \times n$ consists of $n$ elements (requirements) in the rows and columns whose priorities are to be determined. 
Step 2: Perform pair-wise comparisons of all the elements.

Table 1.Saaty's scale

\begin{tabular}{|c|c|}
\hline $\begin{array}{c}\text { Intensity of } \\
\text { Importance }\end{array}$ & Interpretation \\
\hline 1 & Requirement $\mathrm{i}$ and $\mathrm{j}$ are of equal value. \\
\hline 3 & Requirement $\mathrm{i}$ has a slighter higher value than $\mathrm{j}$ \\
\hline 5 & Requirement $\mathrm{i}$ has a strongly higher value than $\mathrm{j}$ \\
\hline 7 & Requirement $\mathrm{i}$ has a very strongly higher value than $\mathrm{j}$ \\
\hline 9 & Requirement $\mathrm{i}$ has an absolute higher value than $\mathrm{j}$ \\
\hline $2,4,6,8$ & These are intermediate scales between two adjacent judgments \\
\hline Reciprocals & If requirement $\mathrm{i}$ has lower value than $\mathrm{j}$ \\
\hline
\end{tabular}

This comparison scale enables the decision-maker to incorporate experience and knowledge intuitively and indicate how many times an element dominates another with respect to the criterion. The decision-maker can express his preference between each pair of elements verbally as equally preferred, moderately preferred, strongly preferred, very strongly preferred and extremely preferred. These descriptive preferences would then be translated into numerical values $1,3,5,7,9$ respectively, with 2, 4, 6 and 8 as intermediate values for comparisons between two successive judgments. Reciprocals of these values are used for the corresponding transposed judgments. For a matrix of $\operatorname{order} n, n(n-1) / 2$ comparisons are required. After the pair-wise comparisons are completed, proceed for the next step to estimate the Eigen values of the matrix.

Step 3: Estimation of the Eigen values of the matrix

In this method, first sum the values in each column of the pair-wise comparison matrix and then divide each element in a column by the sum of its respective column. The resultant matrix is termed as the normalized pair-wise comparison matrix. Finally sum the elements in each row of the normalized pair-wise comparison matrix and divide the sum with the number of elements. The result of this computation is referred to as the priority matrix and is an estimation of the Eigen values of the matrix.

Step 4: Checking the consistency of pair-wise judgments

In order to verify the consistency of the pair-wise comparison matrix, Saaty proposed consistency index $(\mathrm{CI})$ and consistency ratio (CR). The $\mathrm{CI}$ and $\mathrm{CR}$ are defined as follows.

$$
\begin{gathered}
\mathrm{CI}=\frac{\lambda_{\max }-n}{n-1} ; \\
\mathrm{CR}=\frac{\text { C.I }}{\text { R.I }}
\end{gathered}
$$

Where $\lambda_{\max }=$ maximum principal Eigen value of the comparison matrix

$n$ = number of elements (order of the pair-wise comparison matrix) 
The value of $\lambda_{\max }$ is obtained by first multiplying the pair-wise comparison matrix with the priority matrix. Then divide the first element of the resulting matrix by the first element of the priority matrix, the second element of the resulting matrix by the second element in the priority matrix, and so on. A single column matrix is obtained and the average of the elements of the matrix gives the value of $\lambda_{\max }$. The RI in the above equation represents the average consistency index for numerous random entries of same-order reciprocal matrices. The values of RI for matrices of order $n$ are given in table 2

Table 2.Average value of RI for corresponding matrix order (Saaty, 1980)

\begin{tabular}{|c|c|c|c|c|c|c|c|}
\hline$n$ & RI & $n$ & RI & $n$ & RI & $n$ & RI \\
\hline 1 & 0 & 5 & 1.12 & 9 & 1.45 & 13 & 1.56 \\
\hline 2 & 0 & 6 & 1.24 & 10 & 1.49 & 14 & 1.57 \\
\hline 3 & 0.58 & 7 & 1.32 & 11 & 1.51 & 15 & 1.59 \\
\hline 4 & 0.90 & 8 & 1.41 & 12 & 1.48 & & \\
\hline
\end{tabular}

If $\mathrm{CR} \leq 0.1$, then the estimate is accepted; otherwise, a new comparison matrix is solicited until $\mathrm{CR} \leq 0.1$ (Chang et al., 2007)

In the present work, AHP is integrated with Factor analysis and TOPSIS to determine the priority structure of customers' service quality attributes and ranking of different banks.

\subsection{Technique for order preference similarity to ideal solution (TOPSIS)}

Step-1: Construct normalized decision matrix by using the formula,

$$
\mathrm{r}_{\mathrm{ij}}=\frac{x_{i j}}{\left(\sum_{i} x_{i j}^{2}\right)^{1 / 2}} \text { for } \mathrm{i}=1,2, \ldots, \mathrm{m} ; \mathrm{j}=1,2, \ldots, \mathrm{n}
$$

Step-2: Construct the weighted normalized decision matrix. Multiply each column of the normalized decision matrix by its associated weight. An element of the new matrix is:

$$
\mathrm{v}_{\mathrm{ij}}=\mathrm{w}_{\mathrm{j}} * \mathrm{r}_{\mathrm{ij}}
$$

Step-3: Now determine the positive ideal and negative ideal solutions using,

$$
\begin{aligned}
& \text { Positive ideal solution }: \mathrm{V}_{\mathrm{j}}{ }^{*}=\left\{\max \left(\mathrm{c}_{\mathrm{ij}}\right)\right\} \\
& \text { Negative ideal solution }: \mathrm{V}_{\mathrm{j}}{ }^{\prime}=\left\{\min \left(\mathrm{v}_{\mathrm{ij}}\right)\right\}
\end{aligned}
$$

Step-4: Calculate the separation measures for each alternative. The separation from the ideal alternative is:

$$
S_{i}^{*}=\left[\sum_{j=1}^{m}\left(v_{i j}-v_{j}^{*}\right)^{2}\right]^{1 / 2}
$$


Similarly, the separation from the negative ideal alternative is:

$$
S_{i}^{\prime}=\left[\sum_{j=1}^{m}\left(v_{i j}-v_{j}^{\prime}\right)^{2}\right]^{1 / 2}
$$

Step-5: Calculate the relative closeness to the ideal solution $\mathrm{C}_{\mathrm{i}}{ }^{*}$ and the corresponding ranks of different Branches:

\section{CASE STUDY}

$$
\mathrm{C}_{\mathrm{i}}^{*}=\frac{s_{i}^{\prime}}{s_{i}^{\prime}+s_{i}^{*}} ; 0<\mathrm{C}_{\mathrm{i}}^{*}<1
$$

\subsection{Questionnaire survey}

In view of demonstrating methodology, a case study has been undertaken in 4 branches of State Bank of India, Visakhapatnam. After several discussions made with the experts in the quality service, a questionnaire was developed on the expectations of the customers from 5 dimensions of service quality namely Reliability, Responsiveness, Assurance, Empathy and Tangibles. The questionnaire was administrated to 150 customers in each branch (Hair et al.,1995). After receiving their comments, the questionnaire on customer attributes was revised and finalized. The respondents were asked to indicate the degree of importance of the customer attributes (variables from Q1 to Q30) in terms of a five - point Likert scale(1-Low,2-Average,3-Good,4-VeryGood,5Excellent). To make the study broader, respondents with age greater than 18 years familiar with the use of all modern technologies were chosen. Customers who don't have time or not willing are omitted. People who come to bank on behalf of actual customers are omitted from the study. A total of 624 responses were received from the respondents and in which 46 responses are invalid as the respondents filled the questionnaires not properly. However, 578 responses were considered to carry out the factor analysis. The sample questionnaire is presented below: 
International Journal of Managing Value and Supply Chains (IJMVSC) Vol. 6, No. 4, December 2015

Table 3.Sample questionnaire

\begin{tabular}{|c|c|c|c|c|c|c|}
\hline $\begin{array}{l}\text { Mark th } \\
\text { Mentio } \\
\text { scale: }\end{array}$ & $\begin{array}{l}\text { he degree of service quality in Banking Sector to ensure qualitative } \\
\text { nyour response with a tick mark in the appropriate box provided o } \\
\text { l-Low ; 2-Average ; 3-Good ; 4-Very Good }\end{array}$ & & & & & \\
\hline Q.No. & User Attributes & 1 & 2 & 3 & 4 & 5 \\
\hline Q1 & Use of mobile banking technology (mobile banking, ATM ) & & & & & \\
\hline Q2 & Following the rules and regulations & & & & & \\
\hline Q3 & Implementation of green banking facility. & & & & & \\
\hline Q4 & Neat appearance of staff & & & & & \\
\hline Q5 & Considering the time of customer and reducing the waiting time & & & & & \\
\hline Q6 & Efficient security systems and customer information security policy & & & & & \\
\hline Q7 & Special counter for privileged customer & & & & & \\
\hline Q8 & $\begin{array}{l}\text { Accordance of branch hours with the requirements of customers in case } \\
\text { of emergency }\end{array}$ & & & & & \\
\hline Q9 & Facilities such as Chairs, Reception and Air Conditioning & & & & & \\
\hline Q10 & Provision of proper sanitary facilities & & & & & \\
\hline Q11 & Branch proper position in terms of access and car parking & & & & & \\
\hline Q12 & Releasing and sending important news to customers & & & & & \\
\hline Q13 & $\begin{array}{l}\text { Establishing a Bank Information Center about terms and obligations of } \\
\text { the bank }\end{array}$ & & & & & \\
\hline Q14 & Employeas attention to the customer & & & & & \\
\hline Q15 & $\begin{array}{l}\text { Communication and electronic information exchange between banks } \\
\text { through the country }\end{array}$ & & & & & \\
\hline Q16 & Modification for the time of loan borrowing and repayment & & & & & \\
\hline Q17 & $\begin{array}{l}\text { Creation of Mobile units and increasing the number of ATM's in high } \\
\text { transaction environments }\end{array}$ & & & & & \\
\hline Q18 & Possibility of direct communication with senior management & & & & & \\
\hline Q19 & $\begin{array}{l}\text { Showing the position of bank between domestic and foreign banks in } \\
\text { line with intemational standards }\end{array}$ & & & & & \\
\hline Q20 & Availability of receipts and forms & & & & & \\
\hline Q21 & Availability of safe deposit lockers & & & & & \\
\hline Q22 & Understanding the customer nead perfectly & & & & & \\
\hline Q23 & Sending Email \& SMS to specific customers & & & & & \\
\hline Q24 & Knowledge and proficiency of employees & & & & & \\
\hline Q25 & Good relationship between employes and customer & & & & & \\
\hline Q26 & Existence of note counting machine and fake note detectors & & & & & \\
\hline Q27 & Rewards and Presents from the bank & & & & & \\
\hline Q28 & Availability of complaint box & & & & & \\
\hline Q29 & Attractive branch structure and layout of the different sections & & & & & \\
\hline Q30 & Provision of drinking water in benk & & & & & \\
\hline
\end{tabular}




\subsection{Performing Factor Analysis}

Factor analysis is carried out with a view to reduce the list of customer attributes. Kaiser-Meyer Olkin measure of sampling adequacy (KMO) and Bartlett's test of Sphericity were used to examine the appropriateness of the factor analysis. In this work, the factor analysis of the data received from the questionnaire survey was carried out using statistical package for social sciences (SPSS) version 16.0. The Bartlett's test produces a $\chi^{2}$ of 3625 with a significance level of 0.000 , which shows that the sample taken from the total population under study is adequate. The KMO test produces a measure of 0.627 , which further confirms that the adequacy of the sample. The test results are shown in the table 4. The results obtained from the Bartlett's test and KMO test also indicate the suitability of the application of the factor analysis. Hence factor analysis is considered as an appropriate technique for further analysis of the data.

Table 4.Result of KMO and Bartlett's test

\begin{tabular}{|c|c|c|}
\hline \multicolumn{3}{|c|}{ KMO and Bartlett's Test } \\
\hline Kaiser-Meyer-Olkin Measure of Sampling Adequacy. & 0.627 \\
\hline \multirow{3}{*}{ Bartlett's Test of Sphericity } & Approx. Chi-Square & $3.625 \mathrm{E} 3$ \\
\cline { 2 - 3 } & Df & 435 \\
\cline { 2 - 3 } & Sig. & .000 \\
\hline
\end{tabular}

In the language of the factor analysis the proportion of the variance of the particular variable that is due to common factors (shared with other variables) is called communality. Initial communalities are estimates of the variance in each variable accounted for by all components or factors. Extraction communalities are estimates of the variance in each variable accounted for by the factors (or components) in the factor solution. Small values indicate variables that do not fit well with the factor solution, and should possibly be dropped from the analysis.

Table 5.Communalities

\begin{tabular}{|c|c|c|}
\hline Question & Initial & Extraction \\
\hline Q1 & 1.000 & .730 \\
\hline Q2 & 1.000 & .758 \\
\hline Q3 & 1.000 & .604 \\
\hline Q4 & 1.000 & .753 \\
\hline Q5 & 1.000 & .534 \\
\hline Q6 & 1.000 & .608 \\
\hline Q7 & 1.000 & .649 \\
\hline Q8 & 1.000 & .668 \\
\hline Q9 & 1.000 & .639 \\
\hline Q10 & 1.000 & .575 \\
\hline Q11 & 1.000 & .663 \\
\hline Q12 & 1.000 & .768 \\
\hline
\end{tabular}


International Journal of Managing Value and Supply Chains (IJMVSC) Vol. 6, No. 4, December 2015

\begin{tabular}{|l|l|l|}
\hline Q13 & 1.000 & .600 \\
\hline Q14 & 1.000 & .596 \\
\hline Q15 & 1.000 & .638 \\
\hline Q16 & 1.000 & .671 \\
\hline Q17 & 1.000 & .728 \\
\hline Q18 & 1.000 & .705 \\
\hline Q19 & 1.000 & .611 \\
\hline Q20 & 1.000 & .582 \\
\hline Q21 & 1.000 & .741 \\
\hline Q22 & 1.000 & .630 \\
\hline Q23 & 1.000 & .742 \\
\hline Q24 & 1.000 & .708 \\
\hline Q25 & 1.000 & .655 \\
\hline Q26 & 1.000 & .604 \\
\hline Q27 & 1.000 & .656 \\
\hline Q28 & 1.000 & .654 \\
\hline Q29 & 1.000 & .673 \\
\hline Q30 & 1.000 & .610 \\
\hline
\end{tabular}

A Scree Plot is a simple line segment plot that shows the fraction of total variance in the data as explained. A Scree plot is shown in figure 1 which indicates the Eigen values against the number of factors in order of extraction.

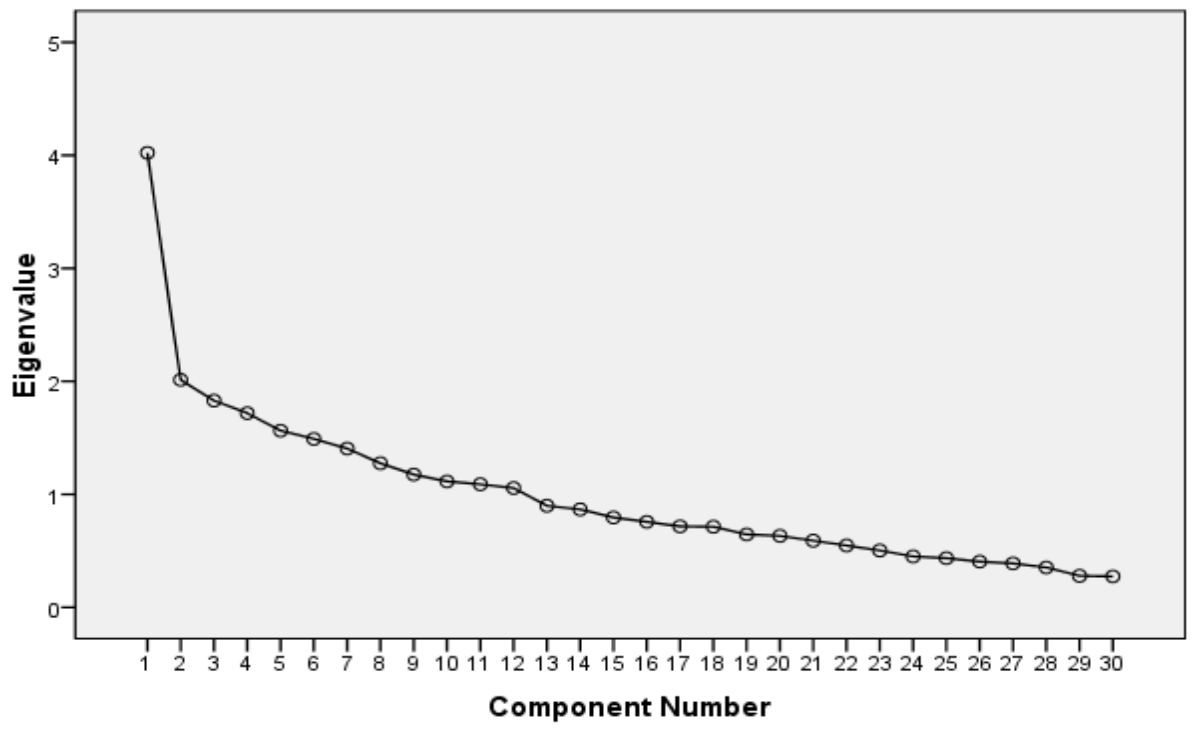

Figure 1.Scree Plo 
International Journal of Managing Value and Supply Chains (IJMVSC) Vol. 6, No. 4, December 2015

Table 6.Rotated Component matrix

\begin{tabular}{|c|c|c|c|c|c|}
\hline \multirow[b]{2}{*}{ Question } & \multicolumn{5}{|c|}{ Component } \\
\hline & 1 & 2 & 3 & 4 & 5 \\
\hline Q14 & .676 & & & & \\
\hline Q25 & .626 & & & & \\
\hline Q22 & .563 & & & & \\
\hline Q24 & .559 & & & & \\
\hline Q5 & .413 & & & & \\
\hline Q9 & & .564 & & & \\
\hline Q20 & & .536 & & & \\
\hline Q10 & & .519 & & & \\
\hline Q23 & & .465 & & & \\
\hline Q6 & & & .584 & & \\
\hline Q18 & & & .534 & & \\
\hline Q8 & & & .434 & & \\
\hline Q21 & & & .416 & & \\
\hline Q7 & & & & .612 & \\
\hline Q11 & & & & .539 & \\
\hline Q28 & & & & .538 & \\
\hline Q29 & & & & .474 & \\
\hline Q30 & & & & .418 & \\
\hline Q16 & & & & & .645 \\
\hline Q3 & & & & & .569 \\
\hline
\end{tabular}

From the table 6, the factors obtained through factor analysis are grouped from 1 to 5 are labeled as Customer Service, Physical Features, Banking Facilities, System and Executive Innovation respectively and are summarized in the table 7 
Table 7.List of customer needs

\begin{tabular}{|c|c|c|}
\hline Sl.No & Variables in the questionnaire & $\begin{array}{c}\text { Factors } \\
\text { (Customer needs) }\end{array}$ \\
\hline \multirow{5}{*}{1} & Employees attention to the customer (Q14) & \multirow{5}{*}{ Customer Service } \\
\hline & $\begin{array}{l}\text { Good relationship between employee and customer } \\
\text { (Q25) }\end{array}$ & \\
\hline & Understanding the customer need perfectly(Q22) & \\
\hline & Knowledge and proficiency of employees(Q24) & \\
\hline & $\begin{array}{l}\text { Considering the time of customer and reducing the } \\
\text { waiting time (Q5) }\end{array}$ & \\
\hline \multirow{4}{*}{2} & $\begin{array}{c}\text { Facilities such as Chairs, Reception, and Air } \\
\text { Conditioning (Q9) }\end{array}$ & \multirow[t]{4}{*}{ Physical Features } \\
\hline & Availability of receipts and forms (Q20) & \\
\hline & Provision of proper sanitary facilities (Q10) & \\
\hline & Sending Email \& SMS to specific customers (Q23) & \\
\hline \multirow{4}{*}{3} & $\begin{array}{l}\text { Efficient security systems and customer information } \\
\text { security policy (Q6) }\end{array}$ & \multirow{4}{*}{ System } \\
\hline & $\begin{array}{l}\text { Possibility of direct communication with senior } \\
\text { management(Q18) }\end{array}$ & \\
\hline & $\begin{array}{l}\text { Accordance of branch hours with the requirements of } \\
\text { customers in case of emergency }(\mathrm{Q} 8)\end{array}$ & \\
\hline & Availability of safe deposit lockers(Q21) & \\
\hline \multirow{5}{*}{4} & Special counter for privileged customers(Q7) & \multirow{5}{*}{$\begin{array}{l}\text { Banking } \\
\text { Facilities }\end{array}$} \\
\hline & $\begin{array}{l}\text { Branch proper position in terms of access and car } \\
\text { parking (Q11) }\end{array}$ & \\
\hline & Availability of complaint box (Q28) & \\
\hline & $\begin{array}{l}\text { Attractive branch structure and layout of the different } \\
\text { sections (Q29) }\end{array}$ & \\
\hline & Provision of drinking water in bank(Q30) & \\
\hline \multirow[t]{2}{*}{5} & $\begin{array}{l}\text { Modification for the time of loan borrowing and } \\
\text { repayment (Q16) }\end{array}$ & \multirow[t]{2}{*}{$\begin{array}{l}\text { Executive } \\
\text { Innovation }\end{array}$} \\
\hline & Implementation of green banking facility(Q3) & \\
\hline
\end{tabular}

\subsection{Analytic hierarchy process (Branches) \\ 3.3.1 Customer Service}

The brainstorming sessions conducted with the experts in the field of banking sector to prepare the pair-wise comparison matrix of different branches with respect to customer service perspective. The pair-wise comparison matrix of the customer service of different branches are shown in table 8 
International Journal of Managing Value and Supply Chains (IJMVSC) Vol. 6, No. 4, December 2015

Table 8.Pair-wise comparison matrix of different branches

\begin{tabular}{|c|c|c|c|c|}
\hline & B I & B II & B III & B IV \\
\hline B I & 1 & 3 & 5 & 2 \\
\hline B II & $1 / 3$ & 1 & 2 & 1 \\
\hline B III & $1 / 5$ & $1 / 2$ & 1 & $1 / 3$ \\
\hline B IV & $1 / 2$ & 1 & 3 & 1 \\
\hline SUM & $\mathbf{2 . 0 3}$ & $\mathbf{5 . 5}$ & $\mathbf{1 1}$ & $\mathbf{4 . 3 3}$ \\
\hline
\end{tabular}

To normalize the sum of the rows, divide the each row by sum obtained from the table 8 . The normalized matrix is shown in the table 9

Table 9.Normalized pair-wise comparison matrix

\begin{tabular}{|c|c|c|c|c|c|}
\hline & B I & B II & B III & B IV & SUM \\
\hline B I & 0.4926 & 0.5454 & 0.4545 & 0.4618 & $\mathbf{1 . 9 5 4 3}$ \\
\hline B II & 0.1642 & 0.1818 & 0.1818 & 0.2309 & $\mathbf{0 . 7 5 8 7}$ \\
\hline B III & 0.0985 & 0.0909 & 0.0909 & 0.0769 & $\mathbf{0 . 3 5 7 2}$ \\
\hline B IV & 0.2463 & 0.1818 & 0.2727 & 0.2309 & $\mathbf{0 . 9 3 1 7}$ \\
\hline
\end{tabular}

The weights of the branches are obtained and given as follows,

$$
\mathrm{W}=\frac{1}{4} \times\left[\begin{array}{l}
1.9543 \\
0.7587 \\
0.3572 \\
0.9317
\end{array}\right]=\left[\begin{array}{l}
0.4885 \\
0.1896 \\
0.0893 \\
0.2329
\end{array}\right]
$$

The weights of the customer service of different branches obtained through AHP are calculated and tabulated in the table 10

Table 10.Weights of the branches for customer service

\begin{tabular}{|c|c|c|}
\hline S1.No & Branches & Weights \\
\hline 1 & Branch I & 0.4885 \\
\hline 2 & Branch II & 0.1896 \\
\hline 3 & Branch III & 0.0893 \\
\hline 4 & Branch IV & 0.2329 \\
\hline
\end{tabular}


International Journal of Managing Value and Supply Chains (IJMVSC) Vol. 6, No. 4, December 2015

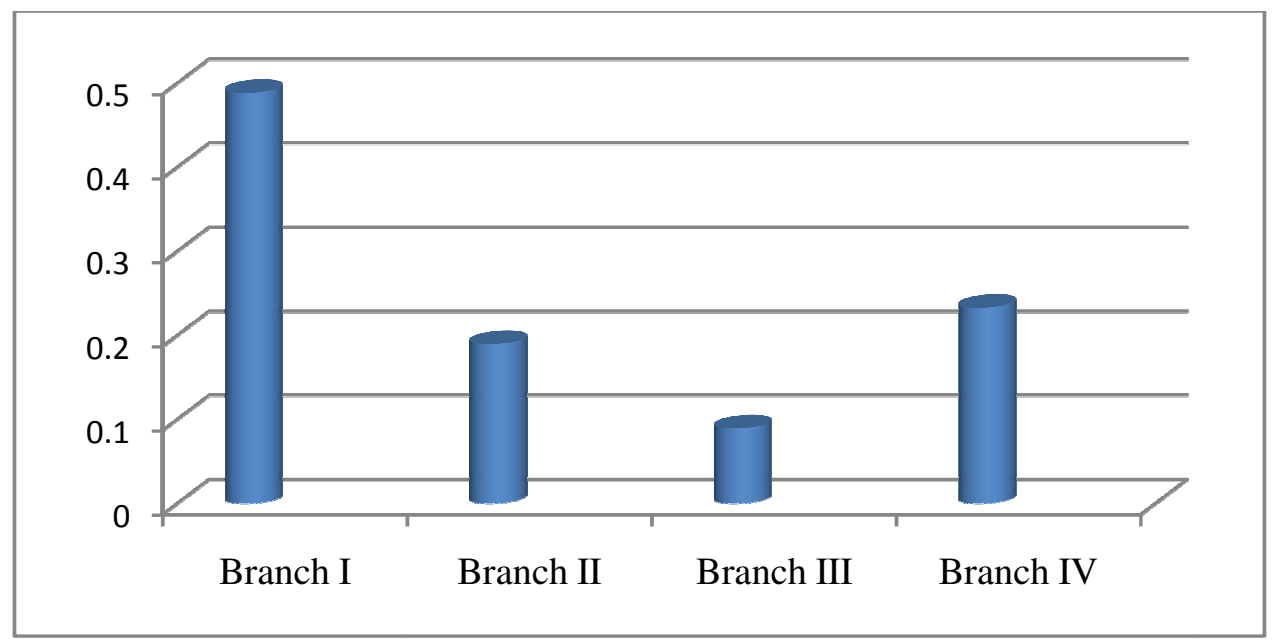

Figure 2.Weights of Branches for Customer Service

The consistency index (CI) and consistency ratio (CR) are calculated using the procedure discussed in the step 4 of the section 2.2 and the computations are given as follows.

$$
\begin{gathered}
{\left[\begin{array}{cccc}
1 & 3 & 5 & 2 \\
0.33 & 1 & 2 & 1 \\
0.2 & 0.5 & 1 & 0.33 \\
0.2 & 1 & 3 & 1
\end{array}\right] \times\left[\begin{array}{l}
0.4885 \\
0.1896 \\
0.0893 \\
0.2329
\end{array}\right]=\left[\begin{array}{l}
1.9696 \\
0.7623 \\
0.3586 \\
0.9346
\end{array}\right](\because \mathrm{v}=\mathrm{A} * \mathrm{~W})} \\
{\left[\begin{array}{l}
1.9696 / 0.4885 \\
0.7623 / 0.1896 \\
0.3586 / 0.0893 \\
0.9346 / 0.2329
\end{array}\right]=\left[\begin{array}{l}
4.0319 \\
4.0205 \\
4.0156 \\
4.0128
\end{array}\right] \quad\left(\because \lambda=\frac{\mathrm{v}}{W}\right)} \\
\lambda_{\max }=\frac{4.0319+4.0205+4.0156+4.0128}{4} \\
\therefore \lambda_{\max }=4.0202
\end{gathered}
$$

Consistency Index (C.I) $=\frac{\lambda_{\max }-n}{n-1}=\frac{4.0202-4}{4-1}=0.00673$

Consistency Ratio $($ C.R $)=\frac{\mathrm{CI}}{\mathrm{RI}}=\frac{0.00673}{0.90}=0.0074(<0.10)$

Similarly, the overall weights obtained through pair wise comparison of Customer Service, Physical Features, System, Banking Facilities and Executive Innovation of different branches are grouped together and are shown in the following Table 11 
International Journal of Managing Value and Supply Chains (IJMVSC) Vol. 6, No. 4, December 2015

Table 11.Pair-wise comparison matrix of various branches and quality dimensions

\begin{tabular}{|c|c|c|c|c|c|}
\hline & CS & PF & ST & BF & EI \\
\hline B I & 0.4885 & 0.5556 & 0.2468 & 0.4189 & 0.1282 \\
\hline B II & 0.1896 & 0.1690 & 0.0940 & 0.2237 & 0.4773 \\
\hline B III & 0.0893 & 0.095 & 0.5015 & 0.1160 & 0.2565 \\
\hline B IV & 0.2329 & 0.1807 & 0.1575 & 0.2415 & 0.1382 \\
\hline
\end{tabular}

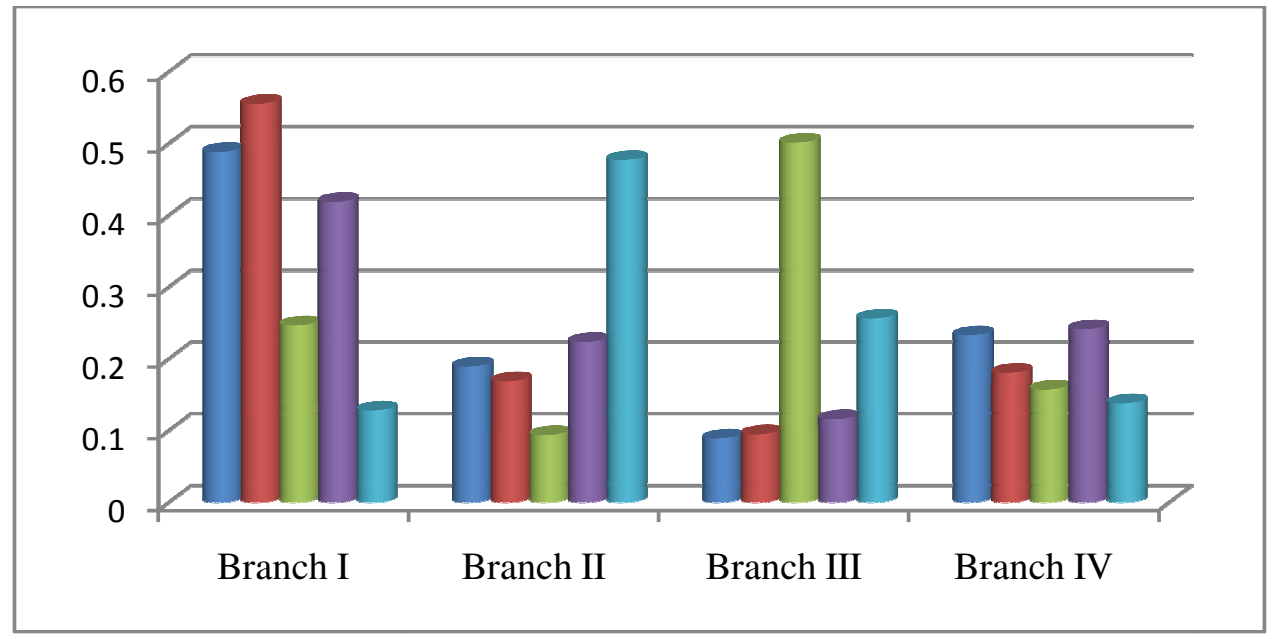

Figure 3.Weights of branches for different criteria

\subsection{Analytic hierarchy process (Quality dimensions)}

\subsubsection{Branch - I}

The brainstorming sessions conducted with the experts in the field of banking sector to prepare the pair-wise comparison matrix of different service quality dimensions with respect to Branches. The pair-wise comparison matrices of the service quality dimension of respective branch are shown in Table 12

Table 12.Pair-wise comparison matrix of different service quality dimensions

\begin{tabular}{|c|c|c|c|c|c|}
\hline & CS & PF & ST & BF & EI \\
\hline CS & 1 & 2 & 1 & 4 & 5 \\
\hline PF & $1 / 2$ & 1 & 2 & 1 & 3 \\
\hline ST & 1 & $1 / 2$ & 1 & 3 & 4 \\
\hline BF & $1 / 4$ & 1 & $1 / 3$ & 1 & 2 \\
\hline EI & $1 / 5$ & $1 / 3$ & $1 / 4$ & $1 / 2$ & 1 \\
\hline SUM & $\mathbf{2 . 5 3}$ & $\mathbf{7 . 2 5}$ & $\mathbf{3 . 8 6}$ & $\mathbf{9}$ & $\mathbf{1 6}$ \\
\hline
\end{tabular}


To normalize the sum of the rows, divide the each row by sum obtained from the table 12 . The normalized matrix is shown in the table 13

Table 13.Normalized pair-wise comparison matrix

\begin{tabular}{|c|c|c|c|c|c|c|}
\hline & CS & PF & ST & BF & EI & SUM \\
\hline CS & 0.3389 & 0.4140 & 0.2183 & 0.4210 & 0.3333 & $\mathbf{1 . 7 2 5 5}$ \\
\hline PF & 0.1694 & 0.2070 & 0.4366 & 0.1052 & 0.2000 & $\mathbf{1 . 1 1 8 2}$ \\
\hline ST & 0.3389 & 0.1035 & 0.2183 & 0.3157 & 0.2666 & $\mathbf{1 . 2 4 3 0}$ \\
\hline BF & 0.0847 & 0.2070 & 0.0727 & 0.1052 & 0.1333 & $\mathbf{0 . 6 0 2 9}$ \\
\hline EI & 0.0677 & 0.0690 & 0.0545 & 0.0526 & 0.0666 & $\mathbf{0 . 3 1 0 4}$ \\
\hline
\end{tabular}

The weights of the quality dimensions is obtained and given as follows,

$$
\mathrm{W}=\frac{1}{5} \times\left[\begin{array}{c}
1.7255 \\
1.1182 \\
1.243 \\
0.6029 \\
0.3104
\end{array}\right]=\left[\begin{array}{c}
0.3451 \\
0.2236 \\
0.2486 \\
0.1205 \\
0.0620
\end{array}\right]
$$

The weights of the different banking service quality dimensions obtained through AHP are calculated and tabulated in the table 14

Table 14.Weights of the banking service quality dimensions

\begin{tabular}{|c|c|c|}
\hline Sl.No & service quality dimensions & Weights \\
\hline 1 & Customer Service & 0.3451 \\
\hline 2 & System & 0.2236 \\
\hline 3 & Physical Features & 0.2486 \\
\hline 4 & Banking Facilities & 0.1205 \\
\hline 5 & Executive Innovation & 0.0620 \\
\hline
\end{tabular}


International Journal of Managing Value and Supply Chains (IJMVSC) Vol. 6, No. 4, December 2015

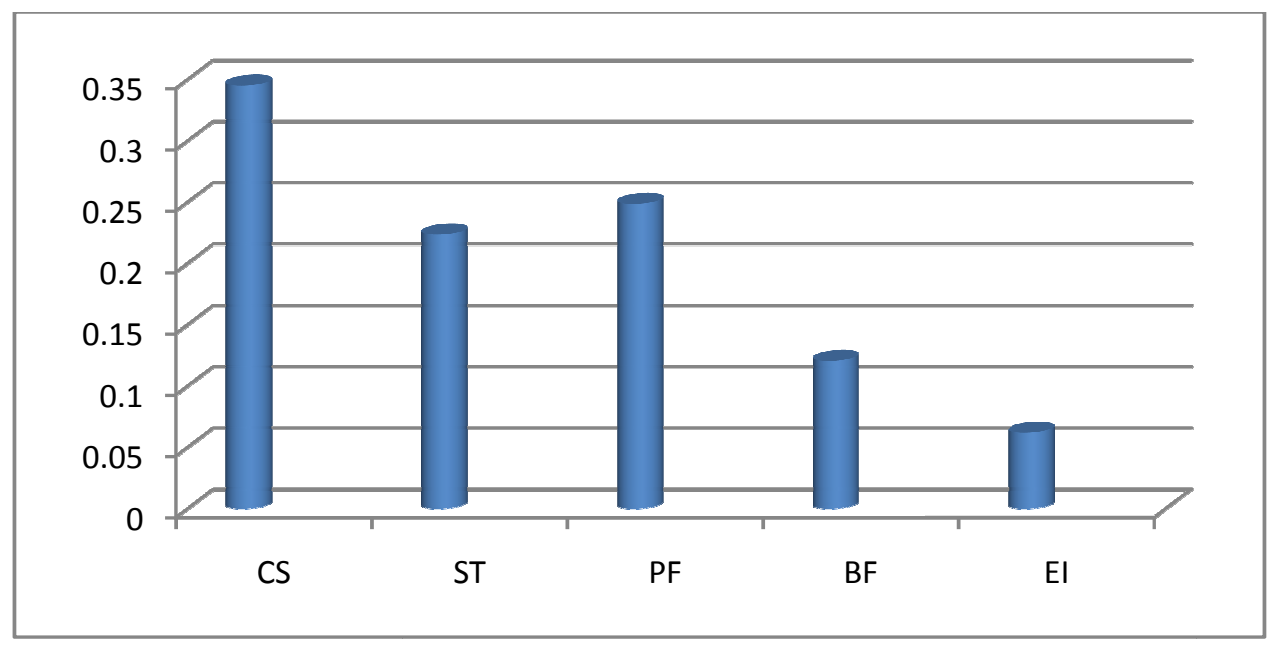

Figure 4.Weights of service quality dimension for Branch I

The consistency index (CI) and consistency ratio (CR) are calculated using the procedure discussed in the step 4 of the section 2.2 and the computations are given as follows.

$$
\begin{gathered}
{\left[\begin{array}{ccccc}
1 & 2 & 1 & 4 & 5 \\
0.5 & 1 & 2 & 1 & 3 \\
1 & 0.5 & 1 & 3 & 4 \\
0.25 & 1 & 0.3 & 1 & 2 \\
0.2 & 0.3 & 0.25 & 0.5 & 1
\end{array}\right] \times\left[\begin{array}{l}
0.3451 \\
0.2236 \\
0.2486 \\
0.1205 \\
0.0620
\end{array}\right]=\left[\begin{array}{l}
1.8329 \\
1.1998 \\
1.3150 \\
0.6364 \\
0.3272
\end{array}\right](\because \mathrm{v}=\mathrm{A} * \mathrm{~W})} \\
{\left[\begin{array}{l}
1.8329 / 0.3451 \\
1.1998 / 0.2236 \\
1.3150 / 0.2486 \\
0.6364 / 0.1205 \\
0.3272 / 0.0620
\end{array}\right]=\left[\begin{array}{l}
5.3112 \\
5.3658 \\
5.2896 \\
5.2813 \\
5.2774
\end{array}\right]\left(\because \lambda=\frac{\mathrm{v}}{\mathrm{W}}\right)} \\
\lambda_{\max }=\frac{5.3112+5.3658+5.2896+5.2813+5.2774}{5} \\
\therefore \lambda_{\max }=5.3050
\end{gathered}
$$

Consistency Index (C.I) $=\frac{\lambda_{\max }-n}{n-1}=\frac{5.3050-5}{5-1}=0.0762$

Consistency Ratio $(\mathrm{C} . \mathrm{R})=\frac{C I}{R I}=\frac{0.0762}{1.12}=0.0680(<0.10)$

The overall weights obtained through pair wise comparison of Customer Service, Physical Features, System, Banking Facilities and Executive Innovation of different Branches are grouped together and are shown in the following Table 15 
International Journal of Managing Value and Supply Chains (IJMVSC) Vol. 6, No. 4, December 2015

Table 15.Pair-wise comparison matrix of different service quality dimensions and branches

\begin{tabular}{|c|c|c|c|c|c|}
\hline & B I & B II & B III & B IV & $\begin{array}{c}\text { Overall } \\
\text { Weights }\end{array}$ \\
\hline CS & 0.3451 & 0.3200 & 0.4383 & 0.3666 & 0.3675 \\
\hline PF & 0.2236 & 0.2106 & 0.2260 & 0.1562 & 0.2041 \\
\hline ST & 0.2486 & 0.3238 & 0.2024 & 0.3028 & 0.2694 \\
\hline BF & 0.1205 & 0.1142 & 0.0830 & 0.1052 & 0.1057 \\
\hline EI & 0.0620 & 0.0577 & 0.0512 & 0.0674 & 0.0476 \\
\hline
\end{tabular}

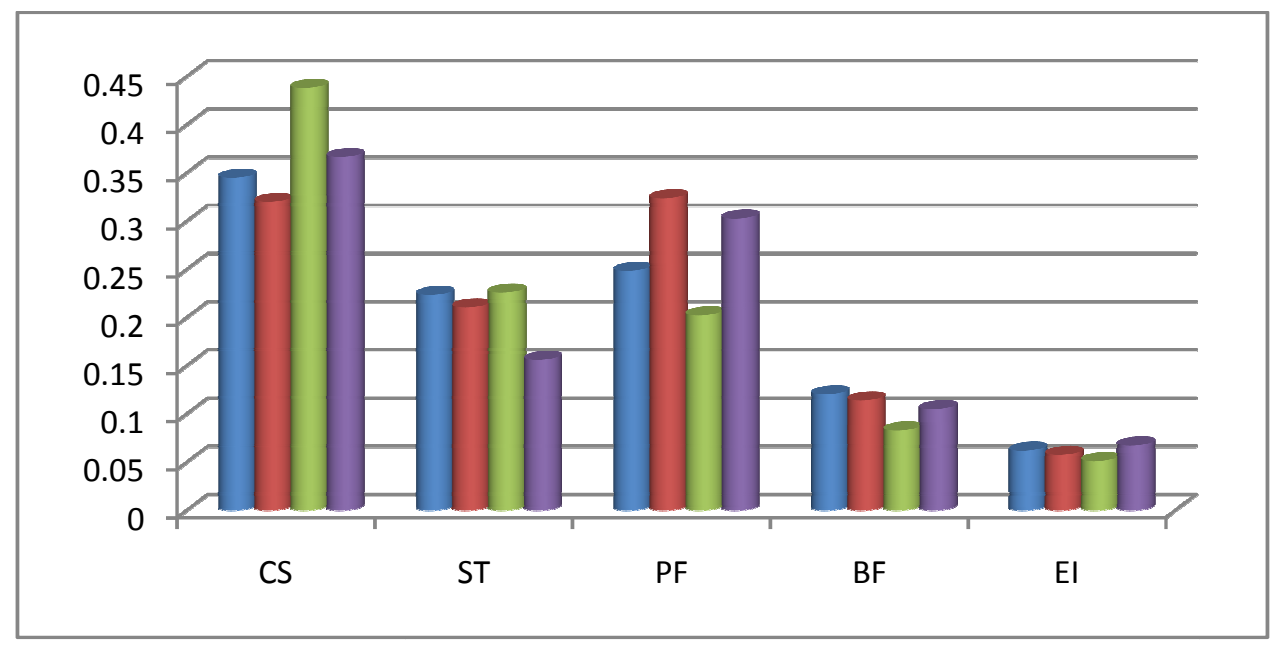

Figure 5.Weights of service quality dimension for different branches

By adding overall weights of the different dimensions to the table 11 we get,

Table 16.Overall weights of different service quality dimensions and branches

\begin{tabular}{|c|c|c|c|c|c|}
\hline Weight & 0.3675 & 0.2041 & 0.2694 & 0.1057 & 0.0476 \\
\hline Branch & CS & PF & ST & BF & EI \\
\hline B I & 0.4885 & 0.5556 & 0.2468 & 0.4189 & 0.1282 \\
\hline B II & 0.1896 & 0.1690 & 0.0940 & 0.2237 & 0.4773 \\
\hline B III & 0.0893 & 0.095 & 0.5015 & 0.1160 & 0.2565 \\
\hline B IV & 0.2329 & 0.1807 & 0.1575 & 0.2415 & 0.1382 \\
\hline
\end{tabular}

\subsection{TECHNIQUE FOR ORDER PREFERENCE SIMILARITY TO IDEAL SOLUTION (TOPSIS)}

Construct normalized decision matrix by using the formula,

$$
r_{i j}=\frac{x_{i j}}{\left(\sum_{i} x_{i j}^{2}\right)^{1 / 2}} \text { for } \mathrm{i}=1,2, \ldots, \mathrm{m} ; \mathrm{j}=1,2, \ldots, \mathrm{n}
$$


International Journal of Managing Value and Supply Chains (IJMVSC) Vol. 6, No. 4, December 2015

Table 17.Normalized Decision Matrix

\begin{tabular}{|c|c|c|c|c|c|}
\hline Weights & 0.3675 & 0.2041 & 0.2694 & 0.1057 & 0.0476 \\
\hline Branch & CS & PF & ST & BF & EI \\
\hline B I & 0.8420 & 0.9029 & 0.4195 & 0.7686 & 0.2235 \\
\hline B II & 0.3268 & 0.2746 & 0.1598 & 0.4104 & 0.8322 \\
\hline B III & 0.1539 & 0.1543 & 0.8526 & 0.2128 & 0.4472 \\
\hline B IV & 0.4014 & 0.2936 & 0.2677 & 0.4431 & 0.2409 \\
\hline
\end{tabular}

Construct the weighted normalized decision matrix. Multiply each column of the normalized decision matrix by its associated weight. An element of the new matrix is :

$$
\mathrm{V}_{\mathrm{ij}}=\mathrm{w}_{\mathrm{j}} * \mathrm{r}_{\mathrm{ij}}
$$

Table 18.Weighted Normalized Decision Matrix

\begin{tabular}{|c|c|c|c|c|c|}
\hline & CS & PF & ST & BF & EI \\
\hline B I & 0.3094 & 0.1842 & 0.0496 & 0.0812 & 0.0106 \\
\hline B II & 0.1200 & 0.0560 & 0.0414 & 0.0433 & 0.0396 \\
\hline B III & 0.0565 & 0.0314 & 0.2296 & 0.0224 & 0.0212 \\
\hline B IV & 0.1475 & 0.0599 & 0.0721 & 0.0468 & 0.0114 \\
\hline
\end{tabular}

Now determine the positive ideal and negative ideal solutions using,

Positive ideal solution $: \mathbf{V}_{\mathbf{j}}^{*}=\left\{\max \left(\mathbf{v}_{\mathrm{ij}}\right)\right\}$

Negative ideal solution $: \mathbf{V}_{\mathbf{j}}^{\prime}=\left\{\min \left({ }^{\mathbf{i j}}\right)\right\}$

Hence,

$$
\begin{aligned}
\mathrm{V}_{\mathrm{j}}{ }^{*} & =\{0.3094,0.1842,0.2296,0.0812,0.0396\} \\
\mathrm{V}_{\mathrm{j}}{ }^{\prime} & =\{0.0565,0.0314,0.04140,0.0224,0.0106\}
\end{aligned}
$$

Now, calculate the separation measures for each alternative. The separation from the ideal alternative is:

$$
S_{i}^{*}=\left[\sum_{j=1}^{m}\left(v_{i j}-v_{j}^{*}\right)^{2}\right]^{1 / 2}
$$

Table 20.Separation measure from Positive Ideal alternative

\begin{tabular}{|c|c|c|c|c|c|c|}
\hline & CS & PF & ST & BF & EI & $\mathbf{S}_{\mathbf{i}}^{*}$ \\
\hline B I & 0 & 0 & 0.0324 & 0 & 0.0008 & 0.1822 \\
\hline B II & 0.0358 & 0.0164 & 0.0354 & 0.0014 & 0 & 0.298 \\
\hline B III & 0.0639 & 0.0233 & 0 & 0.0034 & 0.0003 & 0.3014 \\
\hline B IV & 0.0262 & 0.0154 & 0.0248 & 0.0011 & 0.0007 & 0.2611 \\
\hline
\end{tabular}

Similarly, the separation from the negative ideal alternative is: 
International Journal of Managing Value and Supply Chains (IJMVSC) Vol. 6, No. 4, December 2015

$$
S_{i}{ }^{\prime}=\left[\sum_{j=1}^{m}\left(v_{i j}-v_{j}{ }^{\prime}\right)^{2}\right]^{1 / 2}
$$

Table 21.Separation measure from Negative Ideal alternative

\begin{tabular}{|c|c|c|c|c|c|c|}
\hline & CS & PF & ST & BF & EI & $\mathbf{S}_{\mathbf{i}}{ }^{\prime}$ \\
\hline B I & 0.0639 & 0.0233 & 0.0006 & 0.0034 & 0 & 0.301 \\
\hline B II & 0.0040 & 0.0006 & 0 & 0.0004 & 0.0008 & 0.0761 \\
\hline B III & 0 & 0 & 0.0354 & 0 & 0.0001 & 0.1884 \\
\hline B IV & 0.0082 & 0.0008 & 0.0009 & 0.0005 & 0.0006 & 0.1022 \\
\hline
\end{tabular}

Calculate the relative closeness to the ideal solution $\mathrm{C}_{\mathrm{i}}{ }^{*}$ and the corresponding ranks of different Branches:

$$
\mathrm{C}_{\mathrm{i}}^{*}=\frac{s_{i}^{\prime}}{s_{i}^{\prime}+S_{i}^{*}} ; 0<\mathrm{C}_{\mathrm{i}}^{*}<1
$$

Table 22.Relative closeness and Ranks of branches

\begin{tabular}{|c|c|c|}
\hline BRANCHES & RESULT & RANK \\
\hline BRANCH I & 0.622 & 1 \\
\hline BRANCH II & 0.253 & 4 \\
\hline BRANCH III & 0.471 & 2 \\
\hline BRANCH IV & 0.340 & 3 \\
\hline
\end{tabular}

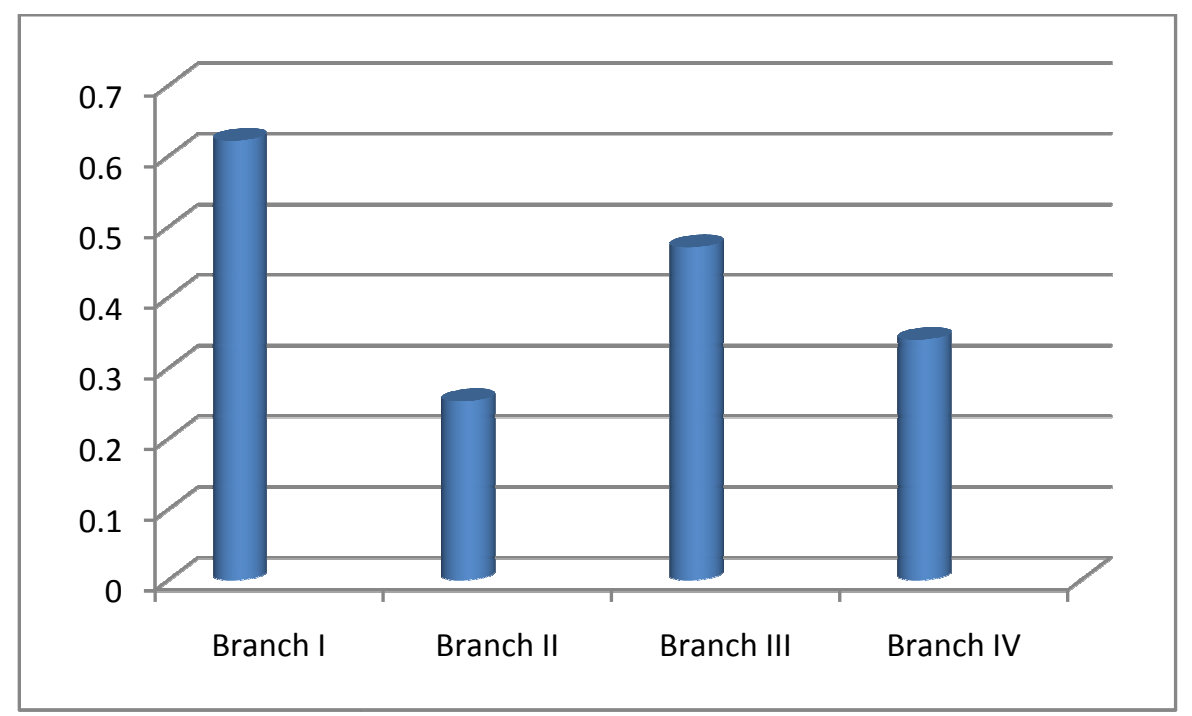

Figure 6.Overall ranking of Branches 
International Journal of Managing Value and Supply Chains (IJMVSC) Vol. 6, No. 4, December 2015

\section{RESULTS AND DISCUSSION}

Quality service is essential to gain competitive advantage in the market place also it helps to sustain customer's confidence. Profit strategy is always linked with excellent services as it results in more business with existing and new customers. The focus of this research is to identify the ways through which banks can improve the quality of their services and extend to which the quality affects the satisfaction level of customers. It was analyzed that the quality of service and customer satisfaction both are crucial factors for success in the business world.

The results from the study show the Ranking of different Branches with respect to different attributes. The satisfaction model will be helpful to determine the overall satisfaction of the banking sector service quality which provides the guidelines in further assessment, betterment and improvement process. Finally, this work introduces an approach that integrates AHP and TOPSIS algorithm to support Banking evaluation decisions.

\section{REFERENCES}

[1] Angur M.G, Natarajan R and Jahera J.S. (1999), "Service quality in banking industry: An assessment in a developing economy", International journal of bank marketing, 17(3), 116-123

[2] Babakus E and Boller G.W (1992), "An Empirical assessment of SERVQUAL scale", journal of business research 24(3), 253-68.

[3] Baumann C, Burton S and Elliott G (2007), "Predicting consumer behavior in retail banking", The journal of business and management, 13(1), 79-96

[4] Brown T.J, Churchill G.A and Peter J.P (1993), "Improving the Measurement of Service Quality", Journal of retailing, 69(1), 127-39.

[5] Hair et al (1995) stated that, "it is generally agreed that the minimum sample for appropriate use for statistical analysis is equal to or greater than 5 time of independent variables, but not less than 100 ".

[6] Hallowell R (1996), "The Relationships of Customer Satisfaction, Customer Loyalty and Profitability: An Empirical Study”, International Journal of Service Industry Management, Vol. 7, No. 4, pp. 27-42.

[7] Hwang.C and Lin.M (1987), “Group Decision Making Under Multiple Criteria,' SpringerVerlag.

[8] Lasser M. C, Monalis and Winson.D (2000), "Service Quality Perspectives and Satisfaction in Private Banking”, Journal of Services Marketing, (14) pp. (2-3).

[9] Levesque.T and Mcdougall G.H.G (1996), "Determinants of customer satisfaction in retail banking" ,International Journal of Bank Marketing, 14 (7), 12-20

[10] Lin, H. C.(2010), "Personnel Selection Using Analytic Network Process and Fuzzy Data Envelopment Analysis Approaches", Computers \& Industrial Engineering (59) 937-944.

[11] Mahmoodzadeh.S, Shahrabi.J, Pariazar.M and Zaeri.M.S , "Project Selection by Using Fuzzy AHP and TOPSIS Technique”, World Academy of Science, Engineering and Technology 30,pp: 333 338, 2007.

[12] Mishra, A. (2009), "A study on customer satisfaction in Indian Retail Banking”, The IUP Journal of Management Research, Vol. VIII, No. 11, pp. 45-61

[13] Pal, M.N., and Choudhury (2009), "Exploring the dimensionality of service quality: An application of TOPSIS in the Indian Banking Industry",Asia-Pacific Journal of Operational Research, 26 (1), 115-133

[14] Parasuraman.A, Zeithamal.V.A and Berry.L.L(1985), "SERVQUAL:A Multiple item scale for measuring customer perception of service quality", Journal of Retailing, 64(1),12 - 40.

[15] Rust.R.T and Oliver.R.C (1994), "Service quality: Insights and managerial implications from the frontier". In Service Quality: New Directions in "Theory and Practice".

[16] Saaty.T.L, The Analytic Hierarchy Process, McGraw-Hill, New York, 1980. 
International Journal of Managing Value and Supply Chains (IJMVSC) Vol. 6, No. 4, December 2015

[17] Saaty.T.L (1990), "How To Make A Decision: the Analytic Hierarchy Process. European Journal of Operation Research",48(1), 9-26.

[18] Shih, S.H., Shyur, H.J., and Lee, E.S., (2007) An extension of TOPSIS for group decision making mathematical and Computer Modeling, 45, 801-813.

[19] Ta, H. P., and Har, K. Y. (2000) A study of bank selection decisions in singapore using the analytical hierarchy process International Journal of Bank Marketing, 18(4), pp170-180.

[20] Venkata Subbaiah.K, Durga Prasad. K.G, Uma Bharathi.K , Soma Sekhara Rao.K (2011). "Integrating factor analysis and Analytic hierarchy process for library service quality" International Journal for Quality research UDK - 005.6:02. Original Scientific Paper (1.01)

[21] Zahedi.F, "The analytic Hierarchy process-A survey of the method and its applications," Interfaces, Vol. 16, pp.343-350, 1977.

[22] Zavadskas.E.K and Turskis.Z (2011) Multiple Criteria Decision Making (MCDM) Methods In Economics: an Overview. Technological and Economic Development of Economy, 17(2), 397427. 